\title{
Las catedrales, focos artísticos del Barroco
}

\author{
Felipe Serrano Estrella* \\ Cathedrals, Baroque artistic spotlights
}

\begin{abstract}
RESUMEN:
ABSTRACT:

Los deseos por parte de obispos y cabildo de llevar a cabo la decoración de la

Bishops and Chapter's desires to carry out the decoration of Jaen's Cathedral with a catedral de Jaén con una calidad similar a su arquitectura, obligaron, con frecuencia, a buscar artistas afamados fuera de la ciudad. Junto a la corte, las relaciones artísticas fueron especialmente intensas con Sevilla, Granada, Córdoba y Málaga.

Los maestros enviaban sus obras o incluso se trasladaban para trabajar al servicio de los promotores catedralicios.

Esta realidad tendrá un notable peso durante el siglo XVI, pero se hace principalmente significativa en las dos centurias siguientes. Valdés Leal, Domingo Martínez, Pedro Roldán, Alonso de Mena o José de Medina, entre otros muchos, conforman la nómina de artistas andaluces que trabajaron para la catedral de Jaén.

PALABRAS CLAVE:

Promoción artística, s. 17, s. 18, Barroco, catedral, obispos, cabildo, pintura, escultura, platería, bordado. similar quality to its architecture obliged them to look for well-known artists away from the town. Close to the court, the artistic relationships were especially intense with Seville, Granada, Córdoba and Málaga. Artists sent their works of art or they moved in order to work for artistic promoters. This situation will have a remarkable influence during the sixteenth century, but it will not become significant until the following two centuries. Valdés Leal, Domingo Martínez, Pedro Roldán, Alonso de Mena o José de Medina, among many others, form the staff of Andalusian artists who worked for Jaen's Cathedral.

\section{KEY WORDS:}

Artistic promotion, seventeeenth century, eighteenth century, Baroque period, cathedral, bishops, chapter, painting, sculpture, silverworks, embroidery.
\end{abstract}

* Universidad de Jaén, Dirección: Edificio C-5, Campus de las Lagunillas, s/n, 23071, Jaén. (953 213441). 
Un objetivo común tuvieron obispos y cabildo como principales promotores de las artes en la catedral de Jaén, ejecutar su decoración de forma competente a la magna arquitectura para la que estaba destinada. No es de extrañar que, en aras de obtener los mejores resultados, encargaran obras a artistas afamados, de diversas procedencias, en especial vinculados a la corte y a los principales focos de producción artística de Andalucía.

Lo que fue una práctica generalizada en el campo de la arquitectura' ${ }^{1}$, ha quedado en un segundo plano en referencia a los bienes muebles. A través de este trabajo queremos demostrar como la catedral de Jaén se erigió en un verdadero foco de promoción inmerso en el mercado artístico de su tiempo, que en determinadas ocasiones condujo a la instalación en la ciudad de aquellos maestros que habían venido para unas labores concretas en el templo, donde descollaron en el ambiente de los siglos XVII y XVIII.

El encargo de obras fuera de la ciudad, la contratación de artistas que venían a Jaén incluso con sus cuadrillas de ayudantes, o aquellos reclamados para ser consultados, bien realizando tasaciones o bien emitiendo informes sobre el proceso de ejecución de obras o las necesidades del templo, etc., constituyen los principales aspectos que conforman esta realidad. Con ellos se pretendía no sólo aportar un criterio de calidad, sino también la imparcialidad que exigían determinado tipo de acciones, aunque tampoco se desatendían las posibles mejores ofertas que venían desde más allá de la propia ciudad y su entorno. La ausencia en algunos momentos de figuras destacadas en los, por lo general, discretos gremios artísticos de la ciudad de Jaén incentivó esta política, en aras de la consecución de un «arredamento» de calidad para el templo mayor.

Baste recordar las palabras del obispo Fr. Benito Marín, cuando al costear unos escaños tallados para el coro, el prelado suplicó [al cabildo] perdonase los defectos que tuviesen por no haber en esta ciudad sujetos que pudieran haberlos ejecutado mejor ${ }^{2}$. No es de extrañar, que cuando Fr. Benito decidiera ornar la capilla en la que sería enterrado, la de San Benito, encargara al sevillano Pedro Duque Cornejo las trazas del retablo, dejando al pucelano Francisco Calvo y al malagueño José de Medina, su ejecución estructural y escultórica ${ }^{3}$.

\footnotetext{
${ }^{1}$ Como ha constatado el profesor Galera Andreu en sus diversos trabajos: GALERA ANDREU, P. A.: Arquitectura de los siglos XVII y XVIII en Jaén. Granada, Caja de Ahorros de Granada, 1979; -Arquitectura y arquitectos en Jaén a fines del XVI. Jaén, Instituto de Estudios Giennenses, 1982; -La catedral de Jaén. León, Everest, 1983; La catedral de Jaén. Madrid, Lunwerg, 2009

2 La idea partió del prelado con el deseo de sustituir los viejos escaños que estaban en el balcón del coro donde se disponían los canónigos «cuando salen a oír los sermones y en otras funciones de primera clase que se celebran en esta Santa Yglesia...» Archivo Histórico Diocesano (A.H.D.J.), Actas Capitulares (A.C.), 4 de marzo de 1756.

${ }^{3}$ Estos datos que aportamos no quieren decir que en el Jaén de las citadas centurias no existieran maestros de estas artes. De hecho los hubo e incluso los vemos trabajando en otros puntos de la diócesis, pero quizás no alcanzaron la consideración necesaria para ser empleados en las grandes obras de la catedral. La brillantez de los gremios artísticos del XVI en Jaén, especialmente en cuanto a escultura y bordado se refiere, decayó considerablemente en la centuria siguiente.
} 
Una práctica que no se entendería sin el carácter itinerante de muchos de los artistas de su tiempo, como ya pusiera de relieve René Taylor en el caso de los retablistas ambulantes del Setecientos, lo que enriquece aún más el ya complejo panorama artístico de la Andalucía barroca ${ }^{4}$.

Este fenómeno contó con buenos precedentes en el Quinientos. Es entonces cuando asistimos a la contratación de una amplia nómina de maestros venidos a Jaén, algunos de los cuales al establecerse en la ciudad generaban no sólo un sólido taller, sino hasta una escuela. Por ejemplo el Maestro Bartolomé, que incluso será denominado como Bartolomé de Jaén, pese a su procedencia castellana. Las labores de ejecución de la sillería del coro atrajeron a gran número escultores foráneos, como Gutierre Alemán o Gierero, Juan López de Velasco o Jerónimo Quijano, entre otros muchos. En el campo de la pintura y retablística la figura más sobresaliente fue la del toledano Pedro Machuca. Esta práctica, lejos de decrecer durante las centurias siguientes, fue en aumento, como a continuación analizaremos.

\section{SEVILLA. UN PUNTO DE REFERENCIA}

La capital hispalense fue un referente de calidad para la promoción artística desarrollada por el cabildo giennense durante el Barroco ${ }^{5}$. Especialmente significativa lo fue en dos momentos concretos, la segunda mitad del siglo XVII y a mediados de la centuria siguiente.

Aunque existen obras de procedencia sevillana que se pueden datar con anterioridad, como la serie angélica de la capilla de San Miguel (hacia 1645), desconocemos su forma de entrada en el templo y solo tenemos constancia de su presencia a partir del XVIII. Por eso, nos tenemos que remitir al encargo del lienzo de San Fernando a Valdés Leal para encontrar un primer ejemplo documentado.

Ante la llegada en abril de 1671 de la noticia sobre la canonización de San Fernando y el recibimiento, dos años después, de la carta de la reina instando a la creación de un altar para que se ferborice la devoción de los fieles a el glorioso santo, el cabildo tomó presuroso la iniciativa y, con el beneplácito episcopal, ordenaba dedicarle un altar, presidido por una gran pintura. Los encargados de llevar a buen término la empresa eran dos de los canónigos más vinculados con las tareas de promoción artística, don Fernando de Zorrilla y don Bernardo de Aguirre, éste último también al frente de la creación del programa iconográfico de la fachada principal, en la que San Fernando ocuparía un lugar preeminente ${ }^{6}$. Para el encargo de este cua-

\footnotetext{
4 TAYLOR, R.: «La familia Primo; retablistas del siglo XVIII en Andalucía» Imafronte, nºs 3-4-5, 198788-89, págs. 323-345.

${ }^{5}$ Así lo puso en evidencia el profesor Valdivieso en el Congreso Internacional La Catedral de Jaén en el 350 Aniversario de su Consagración, con la conferencia «La pintura sevillana en la catedral de Jaén». (Actas del Congreso, en prensa).

${ }^{6}$ A.H.D.J., A.C., 10 y 14 de abril de 1673.
} 


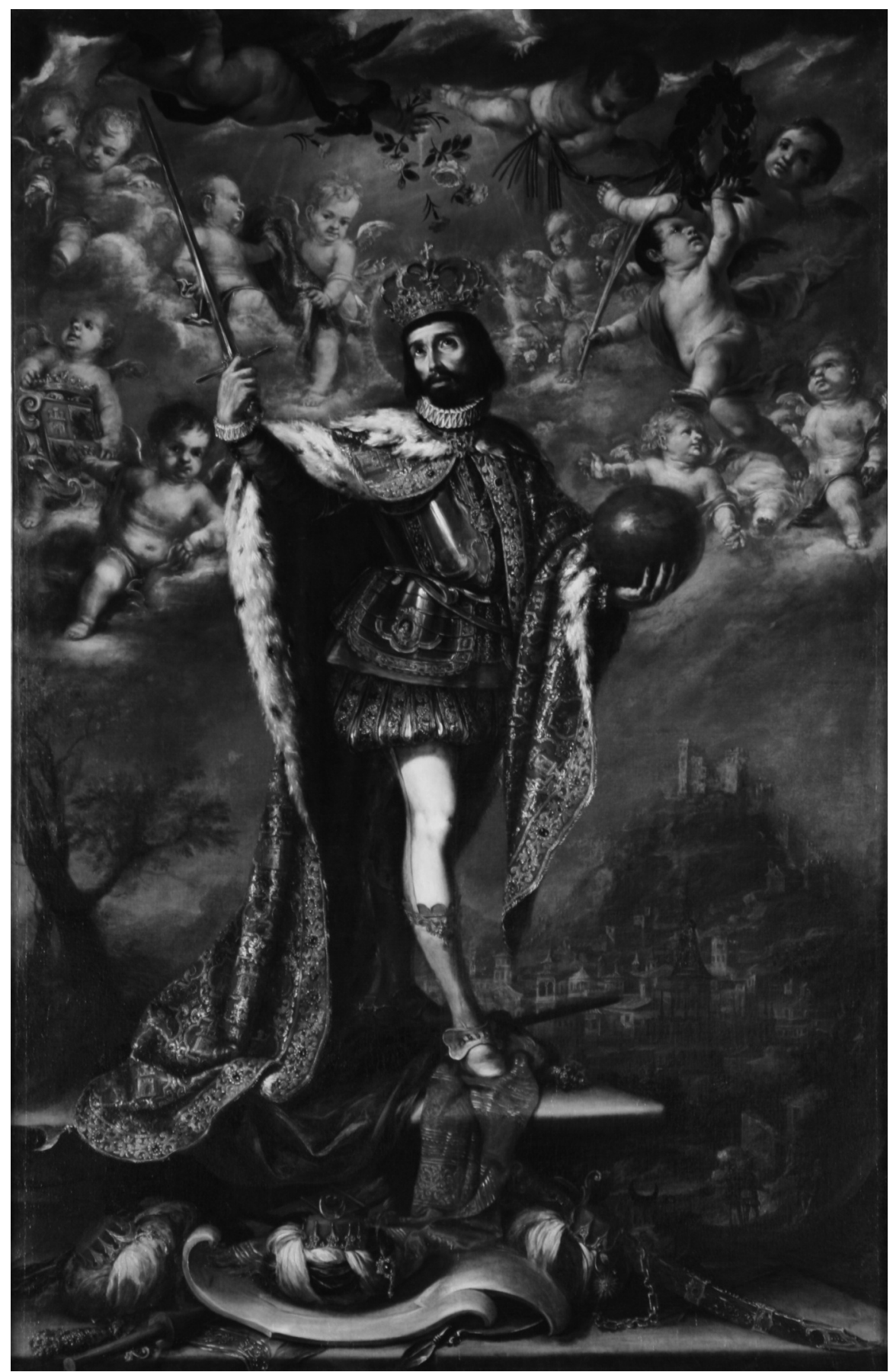

San Fernando, Valdés Leal 1673-1674, óleo sobre lienzo,

Capilla de San Fernando. S. I. Catedral de Jaén. 
dro de altar, dirigen su mirada hacia Sevilla, foco artístico de referencia para el cabildo giennense, más aún cuando el apreciado Sebastián Martínez, casi considerado como «pintor mayor de la catedral», había muerto en 1667. El elegido sería Juan de Valdés Leal (Sevilla 1622 -lbíd. 1690), en plena madurez artística y en un momento de gran fama. La trascendencia de su canonización para la ciudad reconquistada por él, quedaría plasmada en la obra a instancias de los citados canónigos ${ }^{7}$. El resultado es en palabras del profesor Valdivieso una de las mejores obras del artista ${ }^{8}$.

También en relación con la escuela sevillana del Seiscientos encontramos otras obras en la catedral, por ejemplo una Cabeza de San Pablo. Actualmente se conserva en la Exposición Permanente de Arte Sacro, aunque a principios del siglo XX, Romero de Torres, quien la atribuyó a Valdés Leal, la describía en la capilla de la Inmaculada9 . Obra de notable calidad, responde a una temática que gozó de considerable fama, especialmente en Andalucía. Dentro de este género destacó la producción de Sebastián de Llanos Valdés (Sevilla, h. 1605 - Ibíd. 1677), con quien se podría relacionar la tela de Jaén.

Paralelamente al encargo del lienzo de San Fernando en 1673, se emprendía el programa escultórico de la fachada principal, precisamente, presidido por la efigie del rey castellano. El encargo de buscar a los escultores para realizarlo recayó sobre el entonces maestro mayor, Eufrasio López de Rojas ${ }^{10}$. Aunque en un primer momento aparece una terna de nombres: el cordobés Bernabé Gómez del Río y los granadinos Juan Puche y Lucas González, finalmente se contrata con éste último la ejecución de los relieves de la entonces llamada Puerta del Ayuntamiento o de Santa Catalina ${ }^{11}$. Los problemas derivados de la tasación de la obra y el descontento del cabildo con el resultado, condujeron a iniciar nuevas gestiones en mayo de 1675 para traer al escultor sevillano Pedro Roldán (Sevilla 1624 - Ibíd. 1699) ${ }^{12}$. Por él apuestan decididamente el prior de la

${ }^{7}$ A.H.D.J., A.C., 24 de mayo de 1673.

${ }^{8}$ VALDIVİESO, E.: Pintura barroca sevillana. Sevilla, Ed. Guadalquivir, 2003, pág. 456.

${ }^{9}$ ROMERO DE TORRES, E.: Catálogo de los monumentos históricos y artísticos de la provincia de Jaén. T. 1, Jaén, 1913, pág. 213.

10 «(...) que el maestro mayor tome las medidas que fueren necesarias y escriba a los maestros que ubiere del arte de la escultura para que se elija el que fuese más a propósito» A.H.D.J., A.C., 26 de septiembre de 1673.

${ }^{11}$ A Bernabé Gómez del Río se pagaron 300 reales por el viaje a Jaén para presentar sus modelos, mientras que a Lucas González se le pagan 600 reales A.D.H.J., A.C., 11 de febrero de 1674. En mayo se cesaba el contrato con Juan Puche (A.H.D.J., A.C., 6 de mayo de 1674). El propio Pedro Roldán tasaría las obras ejecutadas por González, con el que se ajustó su pago en enero de 1676. A.H.D.J., A.C., 10 de enero de 1676.

${ }^{12}$ Sobre su labor en Jaén: SALAZAR, M. D.: «Pedro Roldán, escultor» Archivo Español de Arte, 88, 1949, págs. 317-339; GALERA ANDREU, P. A.: Arquitectura de los siglos... págs. 163-171; -«La fachada de la catedral de Jaén y la consolidación de la «arquitectura efímera»» en Estudios sobre Literatura y Arte dedicados al profesor Emilio Orozco Díaz. Granada, Universidad de Granada, 1979, págs. 523-531. -»Pedro Roldán en la catedral de Jaén. Nuevas precisiones documentales» Códice, 14, 1998, págs. 31-44; GALIANO PUY, R.: «Las esculturas de la catedral de Jaén (s. XVII). Corpus Documental y Fotográfico» Boletín del Instituto de Estudios Giennenses, 195, 2007, págs. 121-190. 
catedral, don Diego de la Justicia, y el propio Eufrasio López de Rojas, en aras de asegurar una buena obra de la mano de uno de los más afamados artistas del momento ${ }^{13}$. De hecho, el maestro mayor será convocado para avalar ante el cabildo la maestría del nuevo escultor ynformó de la avilidad y suficiencia de Pedro Roldán maestro de escultor que ha venido de Sevilla, con quien en octubre de 1675 se concierta la ejecución de los relieves de la Puerta de los Pilares (lado del Evangelio) con las escenas de la Huida a Egipto y San Miguel. Al tiempo, se pagaba el finiquito a Lucas González -el anterior escultor- previa tasación de Roldán.

Pero la relación del cabildo con el maestro sevillano se complica cuando éste se marcha para atender las obras de la Cartuja de las Cuevas, y deja al frente de la empresa giennense a su sobrino Julián. La idea no es del gusto del cabildo, que exige a Pedro su culminación de acuerdo con lo establecido en el contrato. La estancia de Julián es breve, pues también deja la obra para atender otras demandas fuera de la ciudad. La necesidad de proseguir con la labor escultórica obliga a que a finales de 1676, aprovechando la visita de unas obras por parte de López de Rojas en Marchena, se le encargue que traiga a Julián. Finalmente quien vuelve es Pedro Roldán, que en un primer momento se dedica a terminar los relieves inacabados y a la ejecución de las imágenes de los santos Pedro y Pablo (1677), para más tarde, entre 1683 y 1684, hacer las nueve esculturas de la balaustrada, que serían bendecidas en abril de este último año ${ }^{14}$. El programa iconográfico del conjunto estaba guiado por los canónigos don Bernardo de Aguirre y don Diego de la Justicia, aunque, por la significación del mismo, el resto del cabildo así como por el provisor y el obispo lo vigilarían con gran celo.

El segundo momento en el que Sevilla se convierte en sólido referente para el cabildo lo encontramos a mediados del Setecientos. Se trata de un período de gran efervescencia artística, en especial en el campo de las artes plásticas y suntuarias, pues coincide con la finalización de las obras arquitectónicas del templo. Es entonces cuando encontramos a una serie de promotores artísticos, entre los que destacan obispos como Fr. Benito Marín (1750-1769) y entre los miembros del cabildo, el canónigo don Ambrosio Francisco de Gámez (1693-1762)15. Junto a ellos estarían importantes figuras trabajando para la catedral, por ejemplo los sevillanos Bernardo Lorente Germán, Domingo Martínez y Pedro Duque Cornejo.

Uno de los primeros encargos que recibió el citado canónigo Gámez, fue el de instituir la capilla de la Virgen de los Dolores, materializando la última voluntad del

${ }^{13}$ Será el canónigo don Diego de la Justicia el encargado de escribir al sevillano Pedro Roldán para que venga a tratar de la hechura de las historias que faltan para las puertas de la fachada de la plaza y se le enbien las medidas para que haga los modelos. A.H.D.J., A.C., 20 de septiembre de 1675.

${ }_{14}$ A.H.D.J., A.C., 16 de abril de 1684.

${ }^{15}$ SERRANO ESTRELLA, F.: «La promoción artística en los cabildos catedralicios», en SERRANO ESTRELLA, F. (coord.): Docta Minerva. Homenaje a la profesora Luz de Ulierte Vázquez. Jaén, Universidad de Jaén, 2011, págs. 37-54. 
racionero don Juan Romero Utrera ${ }^{16}$, que le había dejado como albacea junto al arcediano de la catedral. La dotación no era tan extensa como lo requería la decoración que se estaba ejecutando en la misma, de ahí que Gámez tuviera que contribuir con capital propio para su terminación y consumido todo el caudal para perfeccionarla tuve que suplir bastante porción de mis rentas. Con lo qual quedó cumplido dicho albaceazgo ${ }^{17}$.

La obra que nacía estaba dentro de lo que, como veremos, responde a su gusto barroco, una espléndida capilla, totalmente decorada, presidida por un retablo que actúa como marco para un gran lienzo oval dedicado a la Transfixión de María ejecutado por el sevillano Domingo Martínez (Sevilla 1688- Ibíd. 1749)18. En la decoración parietal, que invade todo el espacio, junto a los lienzos creados ex profeso atribuidos a Pancorbo, se aprovechaban obras más antiguas, en concreto los cuatro evangelistas atribuidos a Sebastián Martínez. Una práctica frecuente la de recurrir a obras anteriores, procedentes de otras capillas y de donaciones.

En 1757, frente a la capilla de la Virgen de los Dolores, instituyó a su costa la de San Miguel. En ella recogía una devoción muy vinculada al templo mayor, pues en la catedral vieja existían altares dedicados a San Miguel y a los Ángeles ${ }^{19}$. Para su decoración, Gámez utiliza el modelo que en la década anterior había plasmado en la capilla de los Dolores procurando imitar el mismo adorno (si Dios le diese vida para concluirle, o dejase caudal para ello ${ }^{20}$.

Nuevamente, apuesta por un gran retablo que acoge el lienzo oval del titular, San Miguel, también encargado a un sevillano, esta vez a Bernardo Lorente Germán (Sevilla h. 1680- Ibíd. 1759 ${ }^{21}$, y con el deseo de decorar completamente la superficie pa-

\footnotetext{
${ }^{16}$ Fue prebendado de la catedral, protonotario y juez apostólico, provisor y vicario general del obispado.

${ }^{17}$ Es en su testamento donde la profesora Luz de Ulierte encontró este dato, «quedó un legado de porción de plata labrada y una librería para con su valor dedicar una capilla a María Santísima de los Dolores y dar una dote a una parienta de el susodicho de nueve mil reales de vellón. El que se pagó de pronto vendida la plata y librería y se dedicó la dicha capilla en la nombrada Santa Yglesia...» Archivo Histórico Provincial de Jaén (A.H.P.J.), Protocolos Notariales (P.N.), Leg. 2044, Simón Calvente «Testamento de don Ambrosio Francisco de Gámez», cifr. en: DE ULIERTE VÁZQUEZ, L.: El retablo en Jaén (1580-1800). Jaén, Ayuntamiento de Jaén, 1986, págs. 322-323.

${ }^{18}$ La atribución fue realizada por: VALDIVIESO GONZÁLEZ, E.: «Nuevas pinturas de Domingo Martínez y Andrés Rubira» Archivo Hispalense, 221, 1989, pág. 146 y La Pintura... pág. 539.

${ }^{19}$ A.H.D.J., A.C., 26 de marzo de 1757, «Propuesta del Sr. Gámez y licencia para adornar una capilla y poner una lámpara de plata». Su capilla quedará ampliamente dotada, no solo a nivel artístico sino también devocional, pues instituye una capellanía, una fiesta a San Miguel, limosnas y la dota una lámpara con seis arrobas de aceite. Para ello aplica una herencia que recibió años antes del sacerdote don Francisco de Medina Parra entregada al Hospital de Niños Huérfanos, de ahí que fuera esta institución la encargada de pagar la misa y dotación de la lámpara. A.H.D.J., A.C., 17 de septiembre de 1762 y 8 de febrero de 1765. La herencia la recibió durante su segunda estancia en Baeza en 1750. A.H.D.J., A.C., 11 de septiembre de 1750 .

${ }^{20}$ A.H.D.J., A.C., 26 de marzo de 1757.

${ }^{21}$ ARAGÓN MORIANA, A.: «Noticias en torno a Bernardo Lorente Germán» Senda de los Huertos, 22, 1991, págs. 47-51; VALDIVIESO, E.: La Pintura... pág. 510.
} 
rietal toma unas pinturas que representan una serie angélica, también de escuela sevillana, que Fernández López y Valdivieso atribuyen a Francisco Polanco, fechándolas hacia 1640-165022. Con este pintor cazorleño también se relaciona un Apostolado, incompleto, repartido por diversas estancias de la catedral23.

Como vamos comprobando, el gusto barroco estaba muy asentado entre el cabildo en estas fechas y Sevilla era considerada como un referente de calidad. Esta realidad se vuelve apreciar cuando tras la desacertada venta de la capilla de San Pedro Pascual al canónigo don Fernando del Río (la cual ya tenía propietario desde 1670, el obispo Fr. Jerónimo Rodríguez de Valderas quien la dedicó a San Pedro Pascual), se intente desagraviar la contradicción hecha a la voluntad del prelado y a la devoción al santo a través del encargo de un gran lienzo, que con la calidad del de San Fernando se encargara en Sevilla o Madrid «(...) se dé orden se pinte un lienzo con la efigie del santo por pintor de Sevilla o Madrid que tenga especial habilidad de la misma marca que tiene el de Sr. San Fernando y se coloque en el lugar que éste ocupa (...) ${ }^{24}$. Al año siguiente pensaron que sería mejor una escultura -solicitando a José de Medina su presupuesto- pero finalmente, la falta de medios condujo a contratar el lienzo con un pintor local.

Tras los procesos desamortizadores o como depósito de algunas parroquias han llegado otras obras de escuela sevillana a la catedral de Jaén. Entre los ejemplos más destacados tenemos la Presentación del Niño en el Templo firmada por Juan Ruiz Soriano (Higuera de la Sierra 1701- Ibíd. 1763) que, procedente de la parroquia de San Juan y San Pedro, se conserva en las Galerías Altas de la catedral $^{25}$.

Un capítulo más complejo de analizar, en gran parte por la falta de documentación, es el referente a la labor del también sevillano, Pedro Duque Cornejo (Sevilla 1677 - Córdoba 1757). Sus trabajos se enmarcan precisamente en este momento de gran efervescencia barroca que patrocina el cabildo y el obispo fr. Benito Marín. Por el testamento del artista sabemos que, junto a sus obras en la parroquia de San Ildefonso de Jaén, dejaba tres trazas para retablos en manos del corregidor de la ciudad, del canónigo don Antonio Miranda y del citado prela-

${ }^{22}$ FERNÁNDEZ LÓPEZ, J.: Programas iconográficos de la pintura barroca sevillana del S. XVII. Sevilla, Universidad de Sevilla, 1991, págs. 211-218; -»Los ángeles y los arcángeles de la Capilla de San Miguel de la Catedral de Jaén» Laboratorio de Arte, 8, 1995, págs. 157-173. Desconocemos si esta serie fue donada por el canónigo Gámez o formaba parte de la decoración de la catedral con anterioridad.

${ }^{23}$ En el Inventario de 1918 se dan como obras de Zurbarán, en concreto los dos que se encontraban en la capilla de San Juan Nepomuceno A.H.D.J., Inventarios, Caja 459, «Inventario General de la Santa Yglesia Catedral. Jaén a 9 de septiembre 1918», fol. 68. Asimismo, tenemos constancia de la presencia de obra de Francisco Polanco en una colección particular giennense.

${ }^{24}$ A.H.D.J., A.C., 2 de octubre de 1759.

${ }^{25}$ Desconocemos cuándo llegó a la catedral, quizás en el momento en el que se ejecutó la restauración del templo. La obra ha sido documentada por el profesor Valdivieso. VALDIVIESO, E.: La Pintura... pág. 517. 


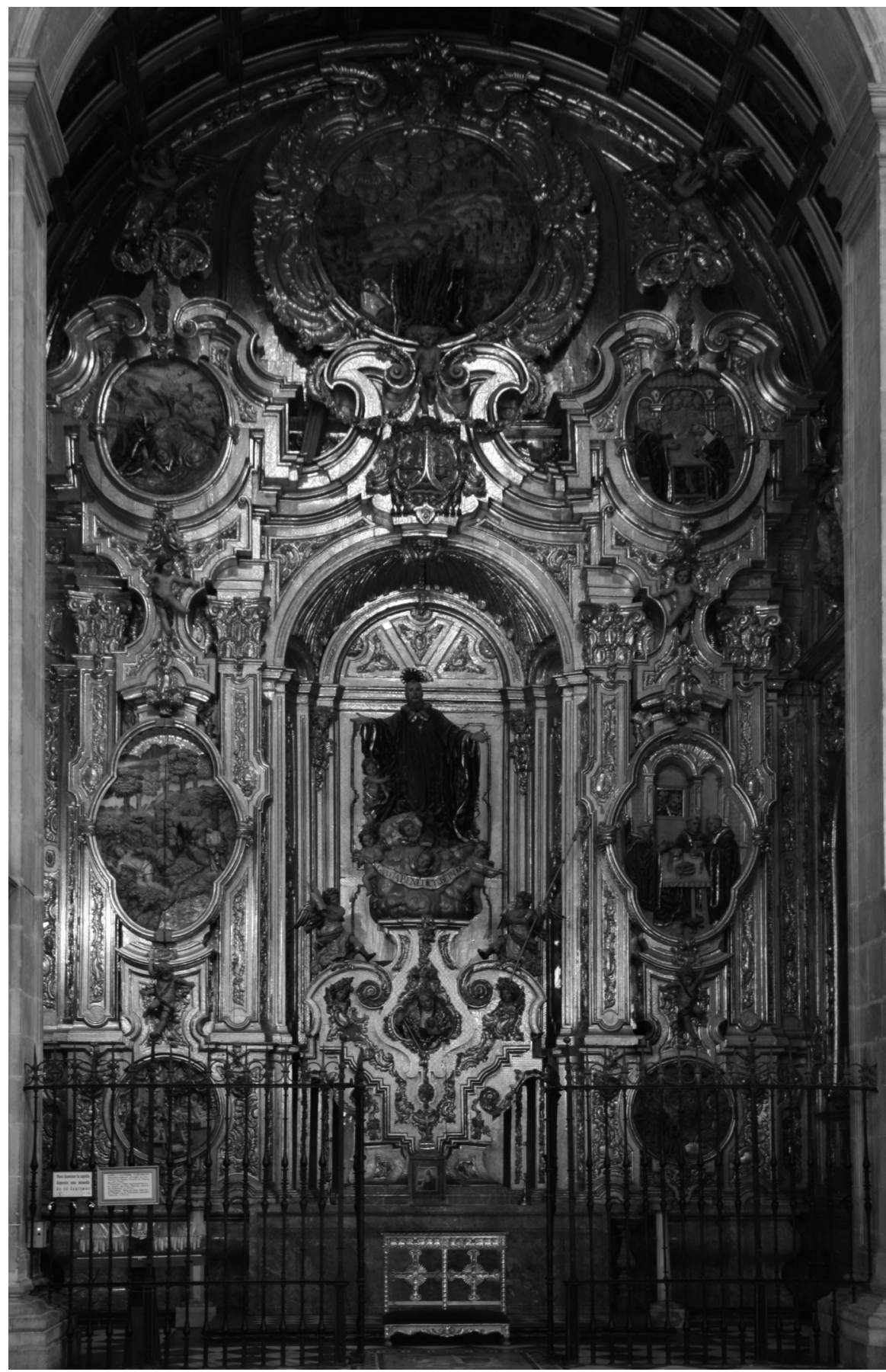

Fig. 2. Retablo de San Benito, Pedro Duque Cornejo 1757, Capilla San Benito. S. I. Catedral de Jaén. 
do $^{26}$. La profesora De Ulierte ha relacionado las dos últimas con los retablos de Santa Teresa y San Benito, que responden claramente al estilo del maestro. Con ellos se pondría un broche de oro a la decoración barroca del templo27. Pero la sombra de Duque Cornejo también planea sobre otros retablos, como el de la Virgen de los Dolores y el de San Miguel, aunque en este último caso, la institución de la capilla en 1757 dificulta esta atribución. Asimismo en ellos, al igual que ocurre en San Ildefonso, podemos situar a Francisco Calvo y José de Medina al frente de su ejecución.

Para terminar con esta intensa relación entre las dos ciudades andaluzas, tenemos que recordar a otro de los campos artísticos en el que Sevilla fue un punto de referencia, el de la fabricación de telas y bordados para los ornamentos sagrados y vestidos de imágenes de gran devoción como la Virgen de la Antigua, la patrona del cabildo de la catedral. Los encargos de ricas telas en Sevilla, muchas de ellas traídas ya bordadas, serán especialmente abundantes en la segunda mitad del siglo XVII, pues en la centuria siguiente se preferirán obradores de Madrid, Toledo y Valencia ${ }^{28}$.

\section{GRANADA, MÁS ALLÁ DE LA PINTURA}

La proximidad y fluidas comunicaciones entre Jaén y Granada se tradujeron en un intenso intercambio artístico entre los dos antiguos reinos, especialmente activo durante los inicios de la Edad Moderna y en los ámbitos fronterizos, como los territorios de la Abadía de Alcalá la Real ${ }^{29}$. La presencia de obras granadinas en puntos tan distantes como Andújar o las Sierras de Cazorla y Segura, se constituye en buena prueba de esta fluida comunicación. Realidad que se hace especialmente visible en la influencia que en las artes plásticas ejerció el foco granadino, sobre todo en la pintura, tal y como pusiera de relieve el profesor León Coloma en el Congreso Internacional La Catedral de Jaén en el 350 aniversario de su consagración.

En el siglo XVII, uno de los nombres más destacados al servicio del templo fue el del escultor Alonso de Mena (Granada 1587 - Ibíd. 1646). El artista trabajó hacia 1640 en la labor escultórica de la denominada "catedral nueva», cuyas obras dirigía Juan de Aranda $^{30}$. Junto a él encontramos a otros maestros de origen tam-

\footnotetext{
${ }^{26}$ VALVERDE MADRID, J.: Ensayo socio-histórico de retablistas cordobeses del siglo XVIII. Córdoba, Monte de Piedad y Caja de Ahorros de Córdoba, 1972, pág. 82.

${ }_{27}$ DE ULIERTE VÁZQUEZ, L.: El retablo... pág. 225.

${ }^{28}$ A.H.D.J., A.C., 12 de agosto de 1661 y 26 de marzo de 1672.

${ }^{29}$ GÓMEZ-MORENO CALERA, J. M.: «Relaciones artísticas entre Jaén y Granada en los inicios de la modernidad: aproximación a una constante histórica» Boletín del Instituto de Estudios Giennenses, 137, 1989, págs. 59-74, trabajo en el que señalaba la amplia nómina de giennenses en tierras granadinas, especialmente en el campo de la arquitectura, y la más limitada de granadinos en Jaén. En el ámbito de la Abadía de Alcalá la Real: GILA MEDINA, L.: Arte y artistas del Renacimiento en torno a la Real Abadía de Alcalá la Real (Jaén). Granada, Universidad de Granada, 1989.

${ }^{30}$ Las obras comienzan a partir de 1635 a instancias del cardenal Moscoso y Sandoval, verdadero promotor de las mismas, que las supervisó con gran cuidado.
} 
bién granadino, por ejemplo Diego de Landeras, que dejó buena parte de su producción en la capital diocesana y que mantuvo una vinculación con el cabildo que fue más allá de la vida del maestro pues, junto a Manuel de Silva, realizó los relieves de las pechinas de la cúpula del crucero $^{31}$.

Las historias en piedra que se habían iniciado en la zona de Vandelvira de la mano de Luis de Aguilar y que se continuaban en la de Aranda con Alonso de Mena, tendrían su culminación en la fachada principal, donde se encargaron en un primer momento a los granadinos Lucas González y Juan Puche. Éste último sería cesado sin comenzar lo acordado, mientras que González, únicamente realizaría los relieves de las Bodas de Caná y Santa Catalina, siendo sustituido por Pedro Roldán ${ }^{32}$.

De igual modo hubo grandes proyectos que se quedaron sin ejecutar, como el retablo de la capilla de San Pedro Pascual en el que iban a intervenir los granadinos Pedro A. Bocanegra (Granada 1638 - Ibíd. 1689), José de Mora (Baza 1642 Granada 1724) y el ensamblador Miguel Romero ${ }^{33}$. Este proyecto, fechado en 1671, arrancó con un gran respaldo económico, la dotación del obispo fray Jerónimo Rodríguez de Valderas (1668-1671), pero las necesidades de la Fábrica absorbieron los bienes destinados a tal fin, entre otras razones por el impago por parte del prelado de la pensión vitalicia de dos mil ducados impuestos sobre la Fábrica para contribuir a su construcción.

En 1735, al tiempo que el entonces maestro mayor, el salmantino José Gallego, terminaba las obras del coro, el cabildo tenía que hacer frente a dos nuevas necesidades. Por un lado, había que ajustar la antigua sillería al nuevo espacio y completar las piezas que faltaban, dado el mayor tamaño del nuevo coro. Un requerimiento que urgía pues había que ubicar a los caballeros del ayuntamiento durante las grandes solemnidades. Para esta obra (adaptar la antigua sillería y completarla) se convoca a escultores de Jaén y Baeza, siendo el baezano Miguel de Arias el encargado de hacer las nuevas piezas ${ }^{34}$.

Una vez resuelto este asunto el cabildo se centra en otro de gran importancia, la ejecución de la caja del órgano, la gran asignatura pendiente de la catedral. Deseban

${ }^{31}$ Gómez-Moreno Calera hace a los Landeras herederos del asentador de la Alhambra, GÓMEZ-MORENO CALERA, J. M.: Op. Cit., pág. 69. Entre las obras atribuidas a Mena en la catedral de Jaén encontramos buena parte de la colección de los bustos-relicario que custodiaba la sacristía mayor. Fuera de la provincia existen otras obras atribuidas a este escultor, como la Inmaculada del antiguo convento de Santa Ana de Andújar, ahora en el monasterio de Jesús María de la misma ciudad. En referencia a las obras de la cúpula de la catedral: GALIANO PUY, R.: Op. Cit., págs. 137-141.

32 GALERA ANDREU, P. A.: «Pedro Roldán...», pág. 32-33 y GALIANO PUY, R.: Op. Cit., págs. 143148.

${ }^{33}$ DE ULIERTE VÁZQUEZ, L.: El retablo... pág. 310.

${ }^{34}$ A.H.D.J., A.C., 11 de enero de 1735. No sabemos qué maestros fueron los que ajustaron la antigua sillería al nuevo coro, obra que se hizo bajo la supervisión de José Gallego. En cuanto a las piezas que faltaban para completar el conjunto no será hasta 1737 cuando se comiencen, dirigidas por el baezano Miguel de Arias (8 y 26 de febrero; 5 y 16 de marzo, de 1737). En enero de 1738 se daba por terminada la sillería, a falta de la coronación que se haría más adelante (A.H.D.J., A.C., 17 de enero de 1738). 
una gran máquina barroca, competente con las proporciones del templo y de su coro, al igual que los que por estas fechas se levantaban en otras catedrales españolas. Para llevar a buen puerto esta obra se contrata en Granada a un equipo de artífices encabezados por Juan Fernández. En esta decisión debió de jugar un papel destacado el entonces maestro mayor de órganos de la catedral, el fraile Sebastián Alejo García, conventual en Granada y maestro de órganos de su arzobispado.

En octubre de 1735 se contrata la obra siendo los canónigos Diego Valero y Antonio de Arroyo los comisionados para este fin. De inmediato comienzan a trabajar, pues tenemos constancia de cómo en diciembre se tenía que dejar bien claro que los maestros que construían la caja del órgano no fueran aplicados por el maestro mayor en las obras de los nuevos sitiales del coro ${ }^{35}$. En julio de 1736 se pide un primer informe a Juan Fernández sobre la evolución de las obras, y le exhortan que la tenga «armada y puesta en su lugar» para el día de la Asunción de ese mismo año ${ }^{36}$. Es entonces cuando empiezan a surgir «ciertos reparos» que parecen orientarse en un primer momento hacia asuntos económicos, pero que más tarde veremos como trascienden esta materia.

En octubre de 1736 el cabildo ya no escondía sus temores, no sólo por cómo se estaba sobrepasando la cantidad de dinero en la que se había ajustado la obra, sino por otras cuestiones mucho más importantes como eran las referentes a la estabilidad de la misma, indicándole que no escatimase en hacerla lo más segura posible ${ }^{37}$.

Sin duda cuestionan la profesionalidad de Fernández, e incluso cesan temporalmente su contrato hasta que se aclararen estos problemas. Por este motivo llaman a los escultores baezanos Arias y Briones para que examinen la obra, siendo el primero el que lo hace ${ }^{38}$. No contentos con esta valoración, piden al Padre Alejo, como maestro de la traza, que compruebe si se está ejecutando conforme a ella, y sobre todo con «la firmeza y seguridad» que debe tener ${ }^{39}$. E incluso, solicitan un tercer informe, el del «maestro de arquitectura» Antonio Primo, que el día 2 de enero de 1737 presenta su memorial sobre la forma de continuar y concluir la caja del órgano ${ }^{40}$.

Tras una serie de consultas con Fernández, referidas principalmente a asuntos económicos, el cabildo lo readmite en enero de $1737^{41}$. En octubre se da por ter-

\footnotetext{
${ }^{35}$ A.H.D.J., A.C., 29 de octubre de 1735 y A.H.D.J., A.C., 2 de diciembre de 1735.

${ }^{36}$ A.H.D.J., A.C., 21 de julio de 1736 y A.H.D.J., A.C., 27 de julio de 1736.

${ }^{37}$ A.H.D.J., A.C., 13 de octubre de 1736.

${ }^{38}$ A.H.D.J., A.C., 30 de octubre de 1736 y 9 de noviembre de 1736 . Mientras tanto preguntan a Juan Fernández qué cantidad y cuánto tiempo hacía falta para terminar la obra, a lo que responde: 8.500 reales y tres meses y medio, con siete oficiales (A.H.D.J., A.C., 31 de octubre de 1736).

${ }^{39}$ A.H.D.J., A.C., 13 de noviembre de 1736. El informe de Alejo explica cómo se tendrá que seguir la obra de la caja, para no afectar a los secretos y registros del órgano y no dictamina nada en contra de Juan Fernández (A.H.D.J., A.C., 1 de diciembre de 1736).

${ }^{40}$ A.H.D.J., A.C., 2 de enero de 1737. Se presenta como «vecino de Andújar».

${ }^{41}$ A.H.D.J., A.C., 8 y 29 de enero de 1737. En un primer momento había indicado que faltaban 24.000 reales para terminar (A.H.D.J., A.C., 4 de diciembre de 1736). Tres días más tarde revisaba la cantidad a la baja 16.000 reales (A.H.D.J., A.C., 7 de diciembre de 1736). Se aprovecha una donación del arcediano de Úbeda para aplicarla en estas obras y en la de la sillería (A.H.D.J., A.C., 29 de enero de 1737)
} 


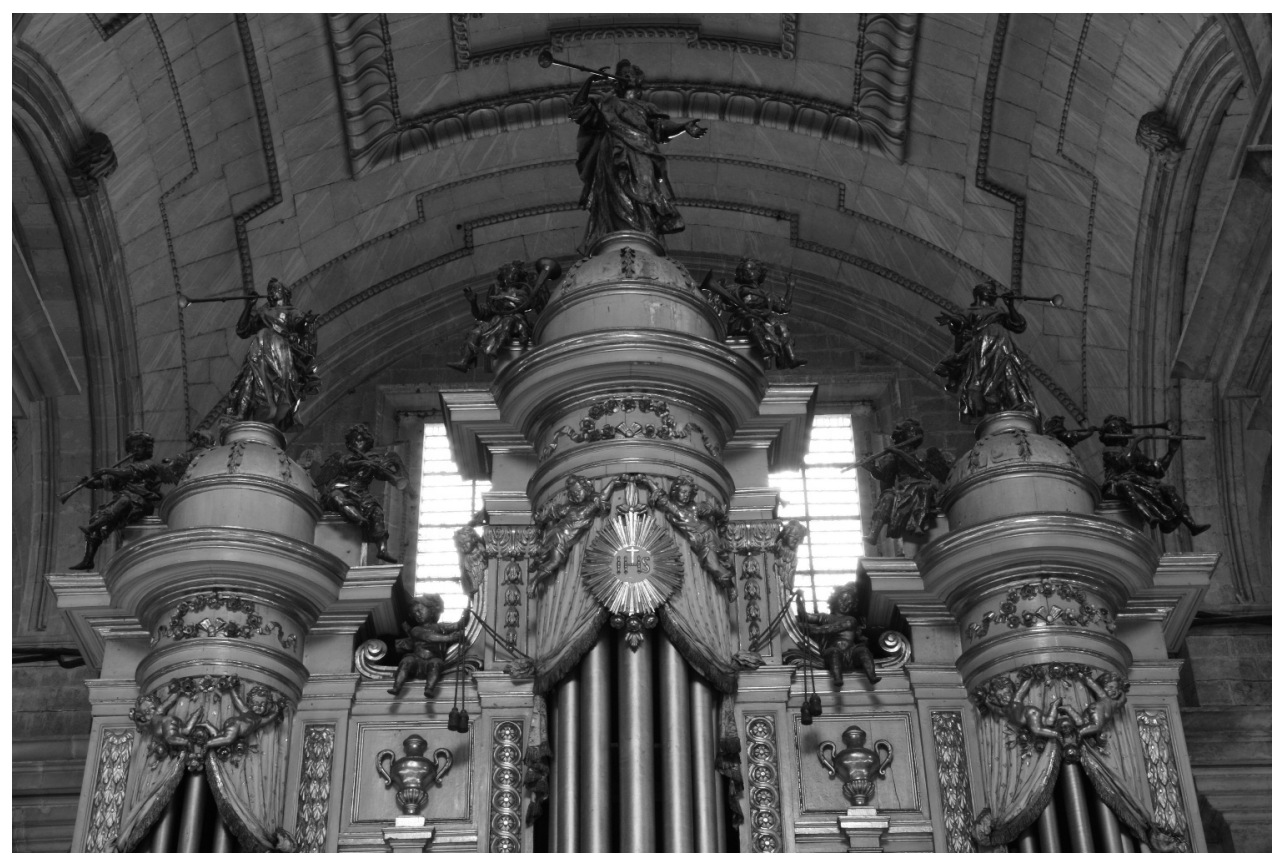

Fig. 3. Esculturas de la caja del órgano, Juan Fernández 1735-1737, S. I. Catedral de Jaén.

minada la obra y el maestro granadino solicita dos mil reales más para los gastos extraordinarios de hierro y madera ${ }^{42}$. Al tiempo, ofrece un proyecto «de adorno de talla» para unir las dos sillerías, la del cabildo y el banco de caballeros ${ }^{43}$. En enero de 1738, pese a haber manifestado los vivos deseos que tenía de servir al cabildo como «Arquitecto y Maestro mayor della en lo tocante a madera», el cabildo le responde agradeciéndole su trabajo y recordándole los escasos medios de los que dispone ${ }^{44}$. Verdaderamente la obra no estaba terminada, faltaban su policromía y dorado. Décadas más tarde, dentro ya del Neoclasicismo se decidía pintar y dorar la caja de dicho órgano con la mayor hermosura posible, dando un color de porcelana a los lisos de ella y de oro a la talla y estatuas. Todo ello con la intervención del arquitecto Manuel López, que en 1790 cobraba por la reforma y aspecto tan gracioso que ha dado a la caja antigua, con lo que contribuía a dar una imagen más clásica que se alejaba de la primitiva obra barroca ${ }^{45}$.

Nuevamente, en esta fase tan barroca de la decoración en la que tiene un papel destacado don Ambrosio de Gámez nos surgen los nombres de figuras que do-

\footnotetext{
${ }^{42}$ A.H.D.J., A.C., 1 de octubre de 1737.

${ }^{43}$ A.H.D.J., A.C., 8 de octubre de 1737.

${ }^{44}$ A.H.D.J., A.C., 14 de enero de 1738.

${ }^{45}$ A.H.D.J., A.C., 12 de enero de 1787 y A.H.D.J., A.C., 9 de enero de 1790.
} 
cumentalmente ya podemos situar al servicio de la catedral, y que contribuyen a potenciar esta imagen del templo como taller artístico del barroco andaluz. Por un lado, la nada desdeñable visita de Antonio Primo, donde se encuentra con su amigo, José de Medina. Y por otro lado, Juan Fernández, con el oficio de Arquitecto y Maestro Mayor de ella [de la catedral] en lo tocante a las obras de madera que es el instituto de su profesión, que se han ofrecido en dicha Santa Iglesia y se le han mandado hacer por dichos SS. Deán y Cabildo, cumpliendo exactamente con su obligación, con el mayor esmero, cuidado y aplicación, las que se habían finalizado por el susodicho con toda integridad y perfección. Todo ello parece constatar que no sólo fue la caja del órgano su gran obra, sino que se ampliaría considerablemente su intervención en las obras escultóricas de la catedral.

En esta «nebulosa» de nombres que están detrás de la imagen más barroca del templo, la profesora De Ulierte planteó la presencia del también granadino Blas Moreno, que como constató Juan Jesús López-Guadalupe, en 1751 realizaba «un prompto viaje a proseguir la obra que tengo principiada de la Santa Iglesia Catedral de Jaén» ${ }^{46}$. Ya la citada investigadora ubicó en Jaén uno de sus trabajos, concretamente el remate del retablo mayor de la iglesia de la Coronada (carmelitas calzados $)^{47}$. Pues bien, para refrendar nuestra teoría sobre los estrechos lazos que se generaron en torno a todos estos maestros y que tienen a Jaén como punto de unión, solo apuntar que, tal y como nos informara el cronista de la referida orden, este retablo mayor era «a semejanza del de Antequera, aunque de distintas manos el cuerpo último o coronación [lo realizado por Blas Moreno]» ${ }^{48}$. Los maestros de la pieza antequerana no eran otros que los Primo y José de Medina.

Otras obras, aparentemente más secundarias, condujeron a la presencia de maestros venidos de Granada, en muchos casos por ofertar a la baja los presupuestos dados por los maestros locales ${ }^{49}$. Así ocurrió con las tareas de enlosado de mármol blanco y negro de la catedral, realizado por «un sujeto de Granada» ${ }^{50}$ de acuerdo con una comisión presidida por el canónigo Gámez, pese a que se había planteado un maestro de la ciudad como su ejecutor.

Algo similar ocurrió con el concierto de la ejecución de las armaduras de plomo de las vidrieras, realizado con el maestro de hojalatero Juan González ${ }^{51}$. Pero el

${ }^{46}$ LÓPEZ-GUADALUPE MUÑOZ, J. J.: «Noticias sobre el escultor y retablista Blas Moreno» Cuadernos de Arte de la Universidad de Granada, 32, 2001, págs. 229-244; DE ULIERTE VÁZQUEZ, L.: «Capillas y retablos en la catedral de Jaén» Elucidario, 3, 2007, pág. 200.

${ }^{47}$ DE ULIERTE VÁZQUEZ, L.: El retablo... pág. 264.

${ }^{48}$ RODRÍGUEZ CARRETERO, M.: Epýtome historial de los carmelitas de Andalucía y Murcia. Primera edición del ms. original 18.118 de la Biblioteca Nacional. Sevilla, Grafisur, 2000, fol. 64v/pág. 83.

${ }^{49}$ En la Exposición Permanente de Arte Sacro se conservan obras de plateros granadinos, como Francisco Sarabia (Portaviático de San Andrés y un juego de candeleros y cruz de altar).

50 A.H.D.J., A.C., 9 de diciembre de 1739.

${ }^{51}$ A.H.D.J., A.C., 3 de septiembre de 1734. Las tareas de ejecución de los balcones de hierro de la fachada principal recayeron en Cristóbal Machado y Pancorbo (A.H.D.J., A.C., 23 de noviembre de 1683). Unos años después, aparecerá con el título de herrero de la Santa Yglesia (A.H.D.J., A.C., 8 de julio de 1689). 
precio presentado no convenció al cabildo, que envió al canónigo don Diego Valero a buscar un maestro herrero en Guadix

«(...) para que reservadamente y a cada uno de por sí haga convocar a los Maestros de herrero de esta Ciudad y trate con ellos de ajuste de los bastidores de hierro que se han de hacer para las vidrieras de esta Santa Yglesia y que enterado dicho Sr. de lo que cada uno pidiere por hacerlos ya sea a jornal, o ya por libras, ajuste con cualesquiera que mejor y con más utilidad de la obra los haga a su satisfacción, dando en todo lo que en este particular y el sitio para poner la fragua todas las providencias que convengan ${ }^{52}$.

Finalmente se rescindía el contrato con González y era el Hermano Cristóbal de Guevara, accitano, el maestro herrero al que se encargarían los bastidores de las vidrieras de la catedral en la zona recién terminada, acordando que montara la fragua en la lonja de la catedral ${ }^{53}$.

Con hierro de las herrerías del duque del Infantado ${ }^{54}$, se comienza el cerramiento de las capillas del nuevo cuerpo (desde el crucero a los pies), siendo el encargado el maestro Alfonso Jiménez de Acuña, herrero de de Jaén. La primera en cerrarse fue la capilla de la Virgen de los Dolores, pero la muerte del maestro mientras trabajaba en la reja de la capilla de San Jerónimo ${ }^{55}$, obligó a buscar un nuevo artífice. Nuevamente lo hicieron en Guadix, siendo el canónigo Santa Olalla el encargado de hacer venir a Francisco Javier Bravo, que un año más tarde daba por terminadas las rejas de las capillas y pedía se le concediese el honor de Maestro de Herrero de las obras de esta Santa Yglesia y que se le pagase lo que se le restare de ellas...a lo que el cabildo accedía ${ }^{56}$. A él también se le encargarían los balcones, ejecutados con hierro de Vizcaya ${ }^{57}$.

Hasta la realización de las campanas obligó a la presencia de maestros foráneos que no siempre dieron buenos resultados. En 1738 se quebraba la llamada "campana gorda» de la catedral, lo que se constituía en un asunto de gravedad que implicaba al propio obispo Cabrejas, quien propuso a un maestro de la corte para que la examine. La respuesta de éste fue fundir la campana, pero el cabildo, poco confiado, buscó más informes sobre el tema, preguntando al giennense José de la Cuesta y al granadino José Corona. Ambos coincidieron en la necesidad de fundir la campana, éste último por once mil reales, frente a los doce mil que

${ }^{52}$ A.H.D.J., A.C., 3 de septiembre de 1734; 7 de septiembre de 1734; 15 de septiembre de 1734.

${ }^{53}$ A.H.D.J., A.C., 19 de octubre de 1734. Para los vidrios, la cosa parece quedar en familia pues se encargan a los herederos del que fuera canónigo de la catedral don Pedro Vivero Coronel, a doce reales la docena. A.H.D.J., A.C., 7 de septiembre de 1734.

${ }^{54}$ A.H.D.J., A.C., 16 de octubre de 1748.

55 Además tienen que afrontar un pleito con los herederos que piden mil novecientos reales, cantidad que el cabildo considera desorbitada. A.H.D.J., A.C., 27 de marzo de 1749.

${ }^{56}$ A.H.D.J., A.C., 5 de noviembre de 1750. En la cerradura de la reja de la capilla de San Sebastián está su firma «FRANCISCO XABIER BRAVO. GUADIX. A. 1750» (cifr. en: VV.AA.: Catálogo monumental de la ciudad de Jaén y su término. Jaén, Instituto de Estudios Giennenses, 1985, pág. 87).

${ }^{57}$ A.H.D.J., A.C., 20 de agosto de 1751 y 19 de octubre de 1751. 
pedía el maestro de Jaén. Cuando ya el obispo había dado el visto bueno a que la obra la hiciera el maestro granadino, José de la Cuesta rebaja la tasación a cuatro mil reales, con lo que el cabildo termina por encargarle el trabajo. El resultado sería nefasto ya que al ser terminada y puesta a examen ante un maestro llamado por el cabildo, éste dictaminó que se había robado una gran cantidad de metal ${ }^{58}$.

Para concluir con las referencias al ámbito granadino, solo apuntar que con la desamortización llegaron obras de esta procedencia a la catedral. Buena prueba de las intensas relaciones artísticas que existieron en el ámbito de la promoción llevada a cabo en los espacios mendicantes. En los conventos de la capital tenemos constancia de obras de granadinos, entre otros, en San Francisco el Real (los lienzos de Bocanegra en el claustro) y en las dos casas de los carmelitas descalzos, monjas y frailes. De esta última procede la Virgen de las Angustias, atribuida a José de Mora.

\section{CÓRDOBA, ÉXITOS Y FRACASOS}

Además de los estrechos contactos que pintores locales como Sebastián Martínez mantuvieron con el foco cordobés, existieron otros artistas de aquella ciudad que trabajaron en Jaén ${ }^{59}$. Ya hemos mencionado al escultor Bernabé Gómez del Río, que vendría con motivo del concurso para la realización de la labor escultórica de la fachada principal ${ }^{60}$. En el campo de la pintura otro cordobés, Francisco Agustín, actuó como epílogo de la decoración pictórica del templo, en concreto con su Santiago matamoros, para la capilla homónima61.

Tampoco dio los resultados pretendidos el anónimo artífice de la clavazón de las puertas de la fachada principal. En su nombramiento y supervisión actuó como mediador el jesuita Pedro de Bustos. Los problemas entre el maestro y el cabildo comenzaron pronto, en primer lugar con la tardanza en el envío del encargo, y después por la mala calidad de las piezas, muy desiguales, tanto por el color del metal como en el asiento de sus cabezas, y torcido de las espigas. Estos malos resultados condujeron a que el canónigo don Carlos de Ulloa ajustara con el maestro local Carlos Ángel, la ejecución de los 500 clavos necesarios para las puertas de la fachada ${ }^{62}$.

Más nefasta para el cabildo fue la presencia de Miguel de Verdiguier al frente del programa escultórico de El Sagrario. Pese a que Ventura Rodríguez proponía

\footnotetext{
${ }^{58}$ A.H.D.J., A.C., 8 de julio de 1738; 8, 12 y 26 de agosto de 1738; 9 de septiembre de 1738; 4, 5 y 12 de diciembre de 1738.

59 VALVERDE MADRID, J.: «Artistas giennenses en el Barroco cordobés» Boletín del Instituto de Estudios Giennenses, 33, 1962, págs. 9-100.

${ }^{60}$ En la tasación de los relieves de Lucas González también interviene el escultor cordobés Gabriel Gómez (GALIANO PUY, R.: Op. Cit., págs. 147-148).

${ }^{61}$ DE ULIERTE VÁZQUEZ, L.: El retablo... pág. 264 y 330.

${ }^{62}$ A.H.D.J., A.C., 22 de agosto de 1730, 19 de septiembre de 1730, 5 de diciembre de 1730.
} 
al académico José Arias, el cabildo y el obispo se decantaron por Verdiguier (Marsella 1706 - Córdoba 1796) escultor estatuario y arquitecto, afincado en Málaga. La recomendación hecha por la catedral de Córdoba en primera instancia, y años más tarde la efectuada por la de Granada, condujeron a su elección ${ }^{63}$. El resultado nuevamente, no fue el esperado, llegando el deán Martínez de Mazas a afirmar de Verdiguier que venía con mayor crédito de habilidad que el que manifestaban estas obras ${ }^{64}$.

También el cabildo recurrió a cordobeses en otros campos artísticos, como el del bordado, esta vez con más éxito. En la segunda mitad del siglo XVII se desarrolló un gran interés por la ejecución de ornamentos, debido a las muchas necesidades planteadas. Con la muerte de los prelados llegaban piezas sueltas, como casullas o capas, lo que conducía al cabildo a tener que completar los ternos con lo que faltaba. Uno de los pontificales más ricos que heredó la catedral fue el del arzobispo-obispo de Jaén don Fernando de Andrade y Castro (1648-1664), que obligó a buscar en Madrid maestros del bordado capaces de completar un terno a partir de una rica casulla bordada ${ }^{65}$. Pero finalmente no fue en Madrid, sino en Córdoba donde se realizaron las dalmáticas y capa, así como otras piezas menores. Sus autores fueron los miembros de un obrador de bordados cordobés que dejaría bastantes obras en la catedral, los Gómez de los Ríos. Taller familiar, pues en la documentación capitular se menciona a Bartolomé, Miguel, Salvador y Jerónimo, maestros con el mismo apellido y rigurosamente contemporáneos ${ }^{66}$.

El resultado fue del agrado del cabildo, que dio otros dos mil reales para la realización de otras piezas, como un paño de cáliz y bolsa de corporales, para el mismo terno. Además se encargaba al canónigo don Bernardo de Aguirre que viera el otro terno rico, también blanco, para estimar «el aderezo» que necesitaba y contratarlo con Gómez de los Ríos por un precio de tres mil reales, de los que dos mil le serían adelantados para la compra del oro y la seda ${ }^{67}$. Tres meses después se le pedía el aderezo de un juego de capas bordadas, que se apreciaba en tres mil quinientos reales y a principios del año siguiente, la ejecución de un frontal negro ${ }^{68}$. Con su obrador, Gómez de los Ríos se convierte en lo que podríamos de-

\footnotetext{
${ }^{63}$ Después de enumerar las muchas obras realizadas en Córdoba, Juan Antonio Carrascal Velli, en nombre del cabildo cordobés concluye «(...) Todo esto me inclinan a que pueden esos SS. sosegar su ánimo, y esperar el desempeño de lo que ha tratado, a no ser que olvide lo que ha sabido o que mude de carácter, conducta y genio, sobre que nadie puede dar, ni fundar seguridades, por la inconstancia de los hombres (...) A.H.D.J., A.C., 3 de mayo de 1772. En el caso de Granada se ensalza su labor en la capilla de San Cecilio A.H.D.J., A.C., 8 de mayo de 1787.

${ }^{64}$ MARTÍNEZ DE MAZAS, J.: Retrato al natural de la ciudad y término de Jaén. Ed. Barcelona, El Albir, 1978, pág. 223.

${ }^{65}$ A.H.D.J., A.C., 26 de abril de 1672. En este mismo año se le encarga un terno blanco valorado en dos mil reales. A.H.D.J., A.C., 27 de septiembre de 1672.

${ }^{6}$ Desconocemos si existe alguna relación entre estos bordadores y la figura, aunque más tardía, de Antonio Gómez de los Ríos, bordador de cámara de Carlos III.

${ }^{67}$ A.H.D.J., A.C., 28 y 30 de agosto de 1673.

${ }^{68}$ A.H.D.J., A.C., 7 y 22 de noviembre de 1673.
} 
nominar «el bordador mayor» de la catedral, protagonista de esta intensa etapa del arte textil69.

Finalmente no podíamos dejar de hacer referencia al arte por el que verdaderamente resplandeció la Córdoba barroca, la platería, que ejerció su influjo más allá de las fronteras peninsulares. Jaén no fue ajena a esta realidad, y pese a la marcada personalidad y fuerza del gremio de plateros de la capital, las relaciones con Córdoba fueron muy estrechas. A lo largo del siglo XVI tenemos referencias a obras cordobesas en la catedral, aunque las más antiguas conservadas son unos jarros de pico del primer cuarto del XVII. La presencia de artistas cordobeses en la capital fue continua, en especial durante la feria de agosto. Asimismo lo fueron los encargos que se realizaron en Córdoba por parte del cabildo, de los cuales aún hoy quedan testimonios, pese a las pérdidas acaecidas durante la Guerra Civil ${ }^{70}$.

No solo se compraban objetos de plata, también se traía a maestros plateros cordobeses a la catedral. Los motivos eran dos principalmente, el primero la tasación de piezas, buscando a miembros ajenos al gremio local, y el segundo intervenciones en piezas de plata de gran valor, como por ejemplo la Custodia Grande de la catedral, verdadera obra maestra realizada por Juan Ruiz el Vandalino, que por su función en la procesión del Corpus Christi necesitaba de un mantenimiento continuo, ya que al ser portada en andas y por ir cubierta con el palio, cuyas varas en ocasiones chocaban con ella, necesitaba de estas intervenciones. Las referencias al «aderezo» de la custodia serán muy frecuentes y en el siglo XVII tenemos constancia de maestros de platería venidos de Córdoba y Granada para el aderezo de la custodia y se tome de las piezas que faltan puesto que de estos golpes con las varas del palio se caían algunas imágenes y motivos arquitectónicos y decorativos. La importancia de la intervención hacía

\footnotetext{
${ }^{69}$ Ya en el siglo XVIII, el pontifical del obispo Cabrejas y Molina (1738-1746) condujo a la búsqueda en Madrid o en Valencia de tela y maestros que bordaran las piezas necesarias para conformar dos ternos, uno rojo y el otro morado, siendo el canónigo don José de Ulloa el encargado de esta empresa (A.H.D.J., A.C., 29 de noviembre de 1746). Con el obispo Rubín de Ceballos se mira a la prestigiosa fábrica de don Miguel Molero en Toledo, de donde se surten muchas Santas Iglesias pues los ternos regalados por el prelado, uno blanco para los días de primera clase (A.H.D.J., A.C., 22 de enero de 1788 y A.H.D.J., A.C., 5 de febrero de 1788) y el rojo para la capilla de San Eufrasio (A.H.D.J., A.C., 12 de mayo de 1789) se fabrican allí, así como algunos vestidos de la Virgen de la Antigua.

${ }^{70}$ La platería de la catedral sufrió un gran expolio durante la Guerra Civil, como atestigua el informe realizado sobre los objetos desaparecidos «Lo robado en objetos de metal y lo destrozado en ornamentos sagrados no es posible precisarlo; basta consignar que al abrirse nuevamente al culto la Santa Iglesia Catedral no existía un solo candelero de que poder servirse». Jaén, 28 de agosto de 1940 (A.H.D.J., Inventarios, Relación de objetos robados durante la Guerra Civil, Caja 459, fol. 6). Tras la misma, la presencia en Madrid del canónigo don Andrés Trillo Marín hizo que llegaran a la catedral obras de diversa procedencia con las que se pretendía sustituir a las desaparecidas durante la contienda. Por ejemplo la Cruz de Cristal de Roca en recuerdo de la Cruz de Jaspe del cabildo. Piezas de talleres madrileños, conquenses o incluso una custodia de la Escuela de Cristo de la ciudad de Cádiz, pasarán a engrosar el patrimonio artístico de la catedral. A.H.D.J., Inventarios, «Inventario de los ornamentos y vasos sagrados enviados a la Diócesis en la 4⿳亠丷a expedición. Madrid 1 de agosto de 1942», fols. 1-5.
} 
que el obispo fuera informado de ella y, por lo general, eran los canónigos más preocupados por cuestiones artísticas y del culto los encargados de su supervisión ${ }^{71}$.

La presencia de obras hechas en Córdoba por maestros plateros de renombre tiene uno de sus hitos en el relicario para el Santo Rostro. En aras de ennoblecer y encauzar la devoción hacia la principal reliquia de la catedral, el obispo don Rodrigo Marín y Rubio (1714-1732) mandó hacer en Córdoba un riquísimo relicario al orfebre José Francisco de Valderrama, así como la urna de plata para custodiarlo ${ }^{72}$. Una mirada a Córdoba que se intensifica desde este momento, no solo por la fama que alcanzan aquellas producciones, sino también por la presencia de canónigos que desempeñan cargos en aquella ciudad. Es el caso de don Francisco Romero y Marín, arcediano de Jaén e Inquisidor en Córdoba que por encargo del cabildo, con especial intervención del canónigo don Ambrosio de Gámez, costeó parte del juego de seis candeleros y cruz, para el altar mayor de la catedral ${ }^{73}$. Esta renovación del ajuar litúrgico exigía o bien pagar por completo las nuevas piezas o amortizar la cantidad de plata empleada. Para ello se entregaba la denominada «plata vieja» que por su mal estado o por presentar un estilo desfasado se enviaba para ser fundida ${ }^{74}$. La catedral también conserva varias piezas de Damián de Castro (Córdoba 1716 - Sevilla 1793), entre ellas un magnífico juego de sacras, cinco candeleros de altar y un hostiario, que quizás se correspondan con las traídas en tiempos del arcediano Romero y Marín. Sí tenemos constancia del encargo realizado por el canónigo Moyano consistente en unas andas de plata para la Virgen de la Antigua, que se corresponden con las conservadas, obra también de Damián de Castro ${ }^{75}$.

Junto a las obras de Valderrama y Castro, encontramos unos atriles de Bernabé García de los Reyes y otras piezas como una salvilla $(1778)$ y una naveta (1791) de Antonio de Santa Cruz y Zaldúa, o un rostrillo (1769), obra de Antonio Ruiz. Todas ellas compartían protagonismo con las procedentes de obradores giennenses que gozaron de gran calidad, en especial los Guzmán, que a su vez, en muchas ocasiones siguieron los gustos marcados por los talleres cordobeses.

\footnotetext{
${ }^{71}$ Desde mediados del XVII era don Pedro de Sahagún uno de los canónigos encargados del mantenimiento de la custodia, y quien recibía la comisión del provisor y obispo para el aderezo de la misma: A.H.D.J., A.C., 25 de agosto y 6 de septiembre de 1661 (hace referencia a plateros cordobeses).

${ }^{72}$ A.H.D.J., A.C., 21 de marzo de 1731 y 30 de marzo de 1731.

${ }^{73}$ A.H.D.J., A.C., 11 de marzo de 1755. A su muerte enviaría una gran cantidad de alhajas de plata con el certificado de Damián de Castro: «El Sr. Mayordomo de Fábrica dé quenta de ciertas alhajas de oro y plata remitidas por el Sr. Arcediano de Jaén para adorno desta Santa Yglesia y comisión para darle las gracias» A.H.D.J., A.C., 10 de abril de 1771. Mercancías que se enviaban bajo custodia de dos soldados.

${ }^{74}$ Romero de Torres nos muestra un magnífico copón de la catedral de Jaén, que pese a ser enviado como «plata vieja» no fue fundido y pasó al Hospital del Cardenal (Córdoba): ROMERO DE TORRES, E.: Catálogo de los monumentos históricos y artísticos de la provincia de Jaén, (fotografías), Jaén, 1913, ( ${ }^{\circ}$ 31), pág. 29.

${ }^{75}$ A.H.D.J., A.C., 26 de septiembre de 1788.
} 


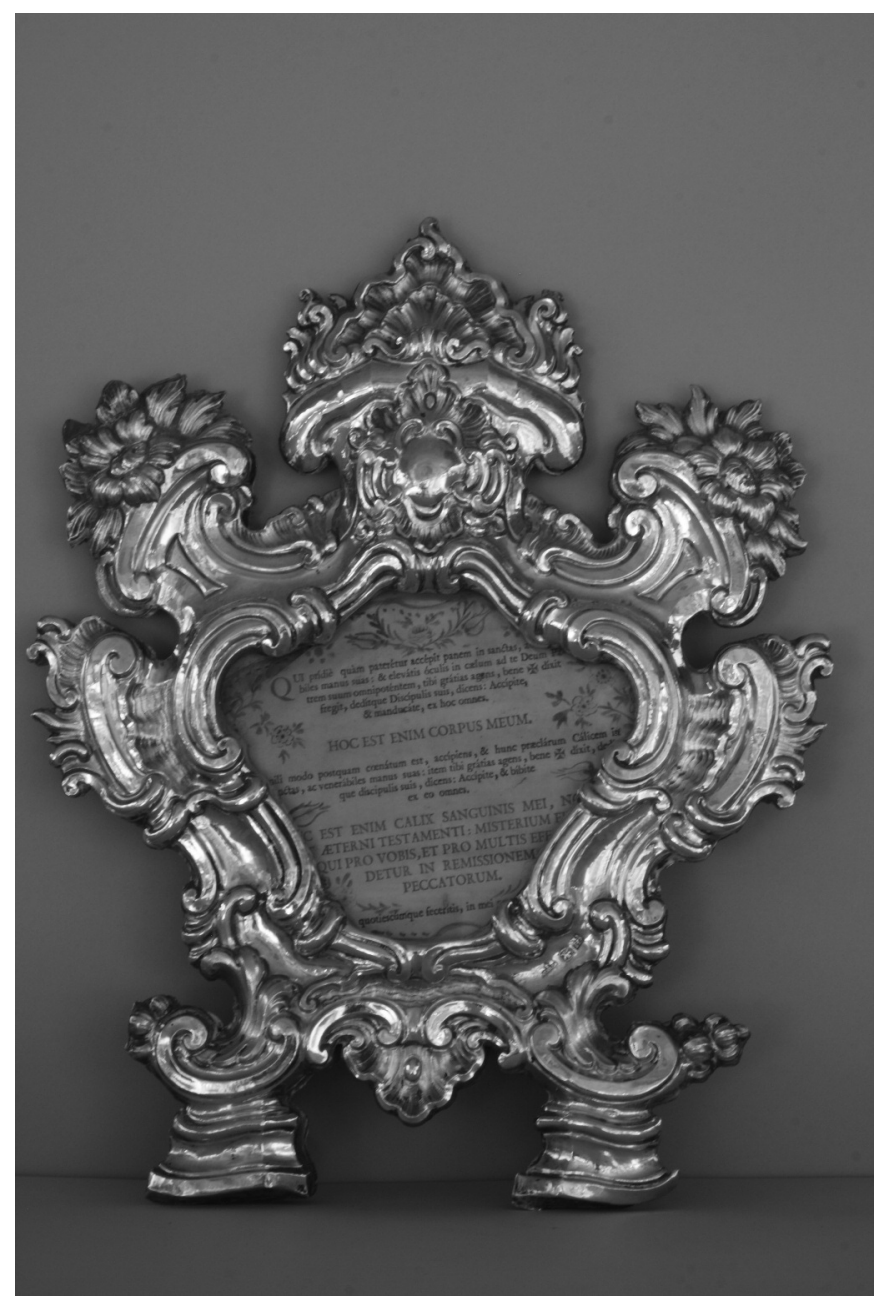

Fig. 4. Sacra, Damián de Castro entre 1759-1767, Exposición Permanente. S. I. Catedral de Jaén.

El 26 de enero de 1770, a petición del propio Miguel de Guzmán, se le nombró maestro mayor de platería de la catedral, argumentando sus años de servicio al templo, al igual que había hecho su padre ${ }^{76}$.

76 «(...) y teniendo presente que el referido ha trabajado y trabaja en esta Santa Yglesia quanto se ofrece y que lo mismo ejecutó su padre; acordaron dichos SS. nombrar y nombraron al referido don Miguel de Guzmán por tal Maestro de Platero para las obras que en esta Santa Yglesia se ofrezcan así de cálices, copones, como de custodias, lámparas, atriles, candeleros, navetas, incensarios y demás alhajas que ocurran correspondiente a su facultad». A.H.D.J., A.C., 26 de enero de 1770. 


\section{MÁLAGA: CLEMENTE RUIZ Y JOSÉ DE MEDINA}

Como hemos podido comprobar uno de los capítulos que necesitó de una mayor dedicación fue el referente a los trabajos del hierro (rejas de las capillas, balcones exteriores e interiores, cierre de las lonjas, etc.). Ya la vieja catedral contó con unas magníficas rejas, algunas de ellas salidas de las manos del Maestro Bartolomé, que luego no fueron aprovechadas en la nueva obra, quizás por problemas de adaptación o bien por no ajustarse a los nuevos gustos.

Para la ejecución de las rejas de las capillas en la zona consagrada en 1660, se llamó a Clemente Ruiz, al que también se cita como Hermano Clemente, quizás por ser miembro de alguna orden tercera $\mathrm{o}$, como ha puesto de relieve el profesor García Cueto, a la cartuja ${ }^{77}$. En un primer momento se le encargó el cerramiento de la capilla mayor, y una vez ejecutado, el propio Clemente Ruiz plantearía la prosecución del resto de rejas, que no eran una prioridad para el cabildo, preocupado especialmente por la de la capilla mayor de acuerdo con las necesidades planteadas por la devoción del Santo Rostro ${ }^{78}$. Finalmente realizaría estas rejas de la zona consagrada, con idas y venidas a Málaga, costeando el cabildo el traslado de su casa. Es a finales de la década de los sesenta cuando desarrolla una labor más intensa al servicio de la catedral ${ }^{79}$.

El otro maestro malagueño, con un gran protagonismo en la configuración de la imagen barroca de la catedral, será el escultor José de Medina (Alhaurín el Grande 1709 - Jaén 1783). Llegado a Jaén en agosto de 1729 al calor de las obras del templo mayor, instituirá incluso una saga de maestros en Jaén ${ }^{80}$. La documentación capitular es parca en noticias sobre este autor, pero cuando se re-

77 Sobre este maestro: GALERA ANDREU, P. A.: «Clemente Ruiz. Un rejero andaluz del XVII, casi desconocido" Boletín de Arte, 6, 1985, págs. 41-54. El profesor García Cueto en el Congreso Internacional La Catedral de Jaén en el 350 Aniversario de su consagración, analizó su producción en Jaén, Granada y Málaga (Actas del Congreso, en prensa).

${ }_{78}$ Más tarde recibirá el encargo de hacer dos postigos en la reja de la capilla mayor para facilitar la adoración de la Verónica, canalizando la gran afluencia de fieles, que entrarían de uno en uno en la capilla mayor y saldrían de igual manera, con lo que nuevamente se ponía de relieve el carácter de templo de peregrinación que era la catedral. A.H.D.J., A.C., 30 de junio de 1674. El dorado de las rejas corrió a cargo del pintor y dorador Juan Troyano, que lo ejecutó en 1663 (A.H.D.J., A.C., 6 de julio de 1663). Para la tasación de la obra, el cabildo nombraría al «maestro dorador» Jacinto de Luque, que junto a Francisco de Miranda, maestro nombrado por Troyano, tasarían la obra del dorado de las rejas de la capilla mayor, vía sacra y coro. A.H.D.J., A.C., 2, 9 y 30 de octubre de 1663.

${ }^{79}$ A.H.D.J., A.C., 25 de septiembre de 1666, 12 de octubre de 1666, 2 de octubre de 1666 (traslado de la casa), 2 de octubre de 1668, 7 de mayo de 1669. En 1669 se pintaban las rejas ya acabadas, en concreto con un betún verdoso, que es el que todavía hoy conservan. AHDJ., A.C., 18 de junio de 1669.

${ }^{80}$ CAÑADA QUESADA, R.: «Escultores en la llustración: José de Medina e Hijos», (Real Sociedad Económica, Ed. Digital: www.realsociedadeconomicajaen.com/congreso virtual/ILUSTRA31htm). Encarcelado a petición de Juana Feliciana Moreno por incumplimiento de su palabra de casamiento, se solicitará su puesta en libertad ya que «está sin poder asistir a el cumplimiento de su obligación que tiene en la obra de la Santa Yglesia Cathedral de la Ziudad, en lo que se le sigue graves daños y pérdidas (...)» A.H.D.J., Matrimoniales, Caja 466 B, «Exp. José de Medina», s/f. 

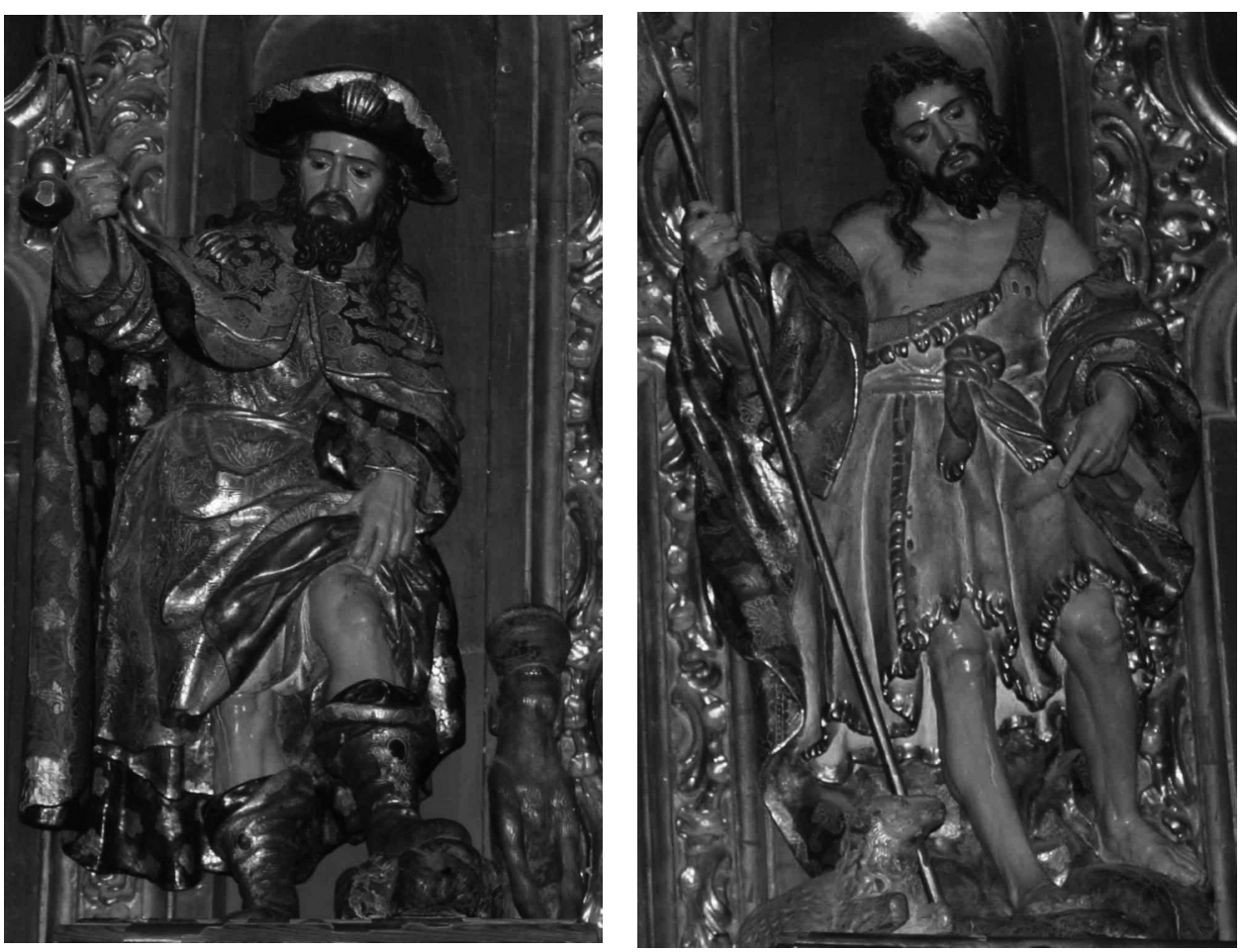

Fig. 5. San Roque y San Juan Bautista, atribuidos a José de Medina hacia 1760, Capilla de Santa Teresa, S. I. Catedral de Jaén.

fiere a él lo hace con una familiaridad que nos recuerda al trato mantenido con Sebastián Martínez ${ }^{81}$.

El escultor malagueño intervino en un primer momento en las labores de escultura en piedra y más tarde, junto a Francisco Calvo, en la ejecución de buena parte de los retablos de la catedral, precisamente durante el momento de gran esplendor vivido con don Ambrosio Francisco de Gámez y Fr. Benito Marín. Es entonces cuando coinciden en la catedral algunos de los maestros más importantes

81 «Se trate con Francisco Calvo y con Medina, sobre el particular de si se podrá proporcionar el hacer en el retablo donde está la pintura de Sr. San Fernando hueco correspondiente para colocar en él una estatua de Sr. San Pedro Pascual de Valencia y consultar con S. S. si será más conveniente se haga de escultura el santo que de pintura, como estaba acordado» A.H.D.J., A.C., 5 de septiembre de 1760. El precio dado por los maestros no fue del agrado del cabildo, de ahí que se retomara la idea de hacer la imagen del santo en pintura. Pero en lugar de buscar maestros de gran calidad, en Madrid o Sevilla, con los que resarcirse del error cometido al vender la capilla al racionero don Fernando del Río, cuando ya tenía propietario, nada más y nada menos que el obispo Fr. Jerónimo Rodríguez de Valderas, finalmente y por cuestiones económicas «acordaron dar comisión al Sr. Chantre para que dé orden se ejecute de pintura por pintor de esta Ciudad que a dicho Sr. pareciere conveniente» A.H.D.J., A.C., 26 de septiembre de 1760 . 
del Barroco andaluz, en determinados casos, unidos por fuertes lazos, como ocurrió con José de Medina y Antonio Primo ${ }^{82}$.

Esta etapa culminaría con las trazas dadas por Duque Cornejo en cumplimiento de los encargos realizados, entre otros, por el entonces obispo, el benedictino fray Benito Marín, ilustrando el intenso comercio artístico vivido en el Jaén del Barroco. Ya fuera por la solicitud de obras a artistas en determinadas ciudades, ya por la llegada de los propios artífices a la catedral, en ese carácter ambulante que reseñara Taylor de los artistas andaluces, la catedral se convirtió en un verdadero foco de recepción de obra de arte, todo bajo una política de promoción artística desarrollada por los obispos de la diócesis y en especial por los propios miembros del cabildo.

${ }^{82}$ Los vínculos entre José de Medina y los miembros de la familia Primo, fueron puestos de relieve por René Taylor. Juntos trabajaron, entre otras obras, en retablos como el mayor de las carmelitas descalzas de Lucena, el mayor del Carmen Calzado de Antequera y en la Vera Cruz de Estepa: TAYLOR, R.: Op. Cit., págs. 323-345. La figura de José de Medina está siendo estudiada por José Luis Romero Torres. 
